\title{
Neuroeconomic Conditioning of the Influence of a Market Demand of Consumers on an Innovative Character of Polish Companies
}

\author{
Anna Gardocka-Jałowiec ${ }^{1}$
}

\begin{abstract}
The aim of the article is an identification of key sources of an innovative character and their conditioning in contemporary Polish economy. In the discussion, it is stated that consumers the smallest, but the most numerous economic unit - through their expectations of the way / form of meeting their own needs, create a direction and dynamics of innovative business and confirm or undermine the legitimacy of accepted directions of actions of the supply side and greatly determine their economic force. In addition, the discussion concerning market decisions (their sources) of consumers and businessmen is based on the results of neuroanatomical brain research. Analyses, that were carried out, allow for stating that: 1) consumers in a market play take on the following roles: creators of an innovative activity based on the reported potential demand; evaluating results of actions taken by innovative businessmen through effective demand; 2 ) in Poland, there has been a gradual redefinition of key factors of innovative character; 3 ) businessmen (over 90\%) consider coming closer to consumers, meeting their needs through the use of the Internet, interactive and social media as the most important initiatives; 4) an action of businessmen within the scope of improving operative efficiency, aiming at accelerating reactions to market consumers expectations increase; 5) brain activity accounts for nearly $3 / 4$ decisions made - each choice constitutes a completely real process engaging a particular neuron number (including von Economo neurons), which influences particular behaviour; 6) a network of neural connections in the brain changes as one gains knowledge and experience - in effect, brain structures become more flexible.
\end{abstract}

Key words: innovation, stakeholder, consumer, consumer information, neuroeconomics, von Economo neurons, mirror neurons.

JEL Classification: D87, 031

'The University of Bialystok, Poland

\section{Introduction}

The existing gap between the innovativeness of Polish and European businesses is revealed by, among other things, annual reports of the European Innovation Scoreboard EIS (2009) ${ }^{1}$. According to the latest edition of the report (January 2010), Poland was ranked 23 among the EU countries, just like in the previous

Corespondence concerning to this article should be addressed to: anna_gardocka@bialan.pl year. According to the results of the study, Poland is characterised by a lower value of the Summary Innovation Index (SII) than the average of all EU countries, but the rate of increase of this index was higher than the EU average (European Innovation Scoreboard, 2009: 6). Owing to the rise in the innovation index, Poland moved from the group of catching up countries to the group of moderate innovators ${ }^{2}$. The monitoring of indices assessing the innovativeness of the Polish economy does not provide unambiguous information 

experience, intuition (the ability to take a broad view of a situation) Undoubtedly, innovativeness, as a characteristic of an entity is an expression of a complex set of skills, a different way of organisation, synthesis, expressing knowledge, perceiving the world and creating new ideas, perspectives, reactions and products.

It is considered that both pecuniary and non-pecuniary criteria (i.e. intensification of competition and of relative efficiency) can be the basis of innovative activity (Cantner, Güth, Nicklisch, Weiland, 2009: 724). Contemporary businesses achieving market success clearly emphasise the role of a system of values in the process of innovation creation in their strategies. Values influence the quality of interactions occurring inside the company and in its relations with the environment. As Bugdol (2006) states, the following qualities are important: trust, fairness, integration, involvement and solidarity. The effectiveness of innovation implementation depends on the form of leadership, personnel attitudes and a recognised system of values (McAdam, Moffett, Hazlett \& Shevlin, 2010: 195-204).

It is worth mentioning that studying various symptoms of trust and its lack is not a contemporary invention. Already liberal thinkers, such as David Hume or James Madison pointed to the significance of trust in economic processes. It is interesting to note that opinions pertaining to trust have not lost their relevance and they are as relevant as they were in the 18th and 19th centuries. As Hardin (2009) points out, contemporary economic reality is far more diversified and complex than the world of our ancestors, which results in both greater trust and also in lack of trust between entities. P. Zak (2008), on the other hand, shows that human attitudes and a recognised system of values affect politics, law and public order are the key for a high standard of living, a prerequisite for economic growth in developing countries. Innovative changes should bring positive economic and/or social effects depending on the area in which they are introduced. The creation of a store of key competences, which should include the ability of systematic and permanent innovative activity, makes it possible to achieve measurable results on the supply side, such as increasing or keeping the market share, winning new market, keeping long-term economic leadership (Grudzewski \& Hejduk, 2008: 243).

As Vyas (2005: 103) notices, innovations are one of the conditions of a company's presence on the market. Some researchers (Prahalad, Krishnan, 2010; Przedpełski, 2005) point out that reliance on innovations created owing to the use of global resources and co-creation of values by clients are of great significance for market activity. Hence, the competitive advantage of large companies in the area of innovative activity is a considerable barrier for small or newly-established companies (Vyas, 2005: 103-116).

Undeniably, innovation is perceived as the key to competitiveness and economic growth (Gilbert, 2006; Horn, 2005: 28). It is pointed out in the National Innovation Initiative Report (Innovation..., 2004: 9) that they contribute to an increase in productivity, cost reduction, an increase in employee satisfaction, eventually leading to the company's higher profits. As the basis of innovative activity, an increase in the dynamics of the company's profits, according to the report devised by The Conference Board ${ }^{6}$, receives low ratings ( $26 \%$ of the respondents) compared to the management's strategy (56\%), the company's customer expectations (52\%) (Źródła i strategie..., 2005: 7-9).

In the method of the Summary Innovation Index calculation recommended for the years 2008-2010, the results of innovative activity block ${ }^{7}$ occurring next to the following blocks: innovation motors ${ }^{8}$, activity of companies ${ }^{9}$ deserves particular attention. The economic innovation effects including: the employment structure, the quantity of exports, sales of new or modernised products are distinguished in the innovative activity group. And, after all, it is the sales index - its value and the dynamics of growth - reflects the level of acceptance of translating the potential demand into the effective demand. The incompatibility of expectations with the market offer manifests itself by lack of demand for specific goods and services. As a result, it is necessary to undertake further innovative actions. Hence, the consumer should not be regarded merely as the party assessing the compatibility of the results with the expectations (the level of the correlation between the potential demand and the effective demand). The consumer should also be perceived (or perhaps primarily so) as the creator of sources of necessary innovative actions aimed at transforming the expectations into approved and recogniszed results (Balsano, Goodrich, Lee, Miley, Morse \& Roberts, 2008: 23). 

Fig. 1. The loop of market dependence between the consumer and the company based on soft and hard conditions of economic activity
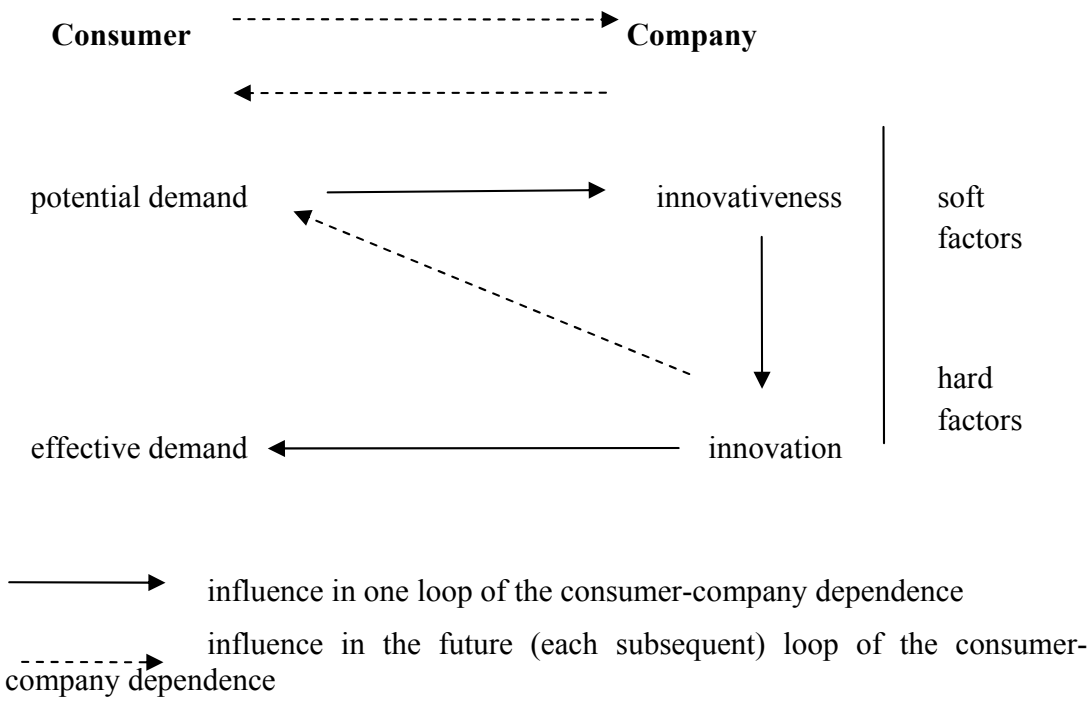

Source: prepared by the author.

ICT, companies are capable of getting to the sources of ideas. For examples, companies can use ICT tools to acquire information about the client (e.g. about their current and future attitude towards specific products and services) (Awazu, Baloh, Desouza, Wecht, Kim \& Jha, 2009: 51).

In a survey conducted in 2007 in a group of 1000 consumers, $53 \%$ of the respondents stated that they used the Internet to compare the characteristics and prices of products and $10 \%$ sent messages to their family and friends while shopping to acquire information or share knowledge (IBM, CEO Study, 2010).

Over $90 \%$ of surveyed Polish entrepreneurs (Fig. 2) point out that getting closer to consumers is their most important strategic initiative in the next years. They consider the Internet as well as interactive and social media channels to be the main sources for establishing such contacts. These contacts are perceived as the basis for understanding and initiating changes in relations with consumers. The results of the research are additionally corroborated by the conclusion of the analyses conducted by the Institute of Market and Social Opinion Research ordered by RSCG Poland stating that companies willing to gain the competitive advantage in the future should have another objective apart from the profit, i.e. be socially involved, respect consumers and conduct an open dialogue with them (Grudzewski, Hejduk, Sankowska \& Wańtuchowicz, 2010: 25).

In this way, the recognition of the factor encouraging companies to undertake innovative activity is on the increase in Poland, i.e. "forcing innovation by clients” (Żołnierski, 2005: 20), while in the years 19982000 the survey conducted among companies by the Central Statistical Office (GUS) showed the following reasons for the introduction of innovation in Polish companies (GUS, Innovative activity, 2001):

- improvement in the product quality $(64.5 \% \mathrm{com}$ panies employing over 49 people and $63.1 \%$ companies employing 10-49 people);

- opening new markets or increasing the market share (58.1\% companies employing over 49 people and $54.2 \%$ companies employing $10-49$ people);

- increasing the range of products (57.4\% companies employing over 49 people and $53.4 \%$ companies employing 10-49 people). 
Fig. 2. Aspects of company activity in the following years

Getting closer to consumers

Interpersonal skills

Conclusions and data collection

Changes in the company model

Risk management

Changes in the line of business model

Changes in the revenue model

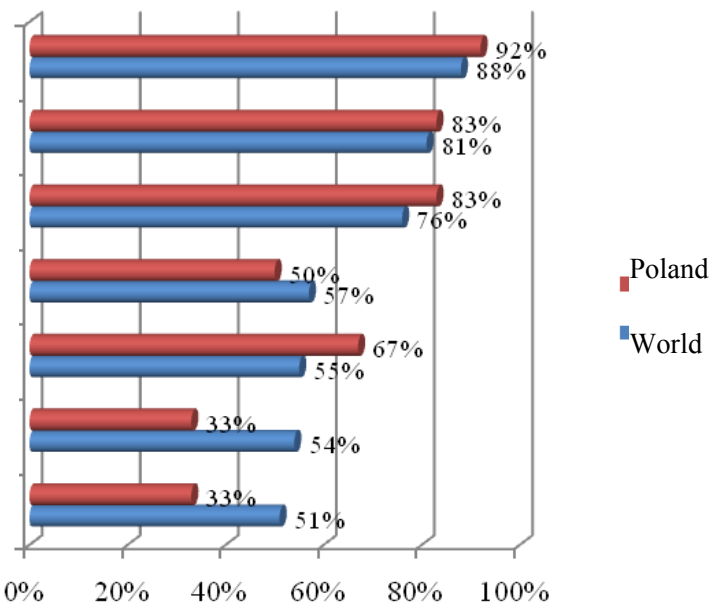

Source: http://www.networkmagazyn.pl/najwazniejsza-cecha-prezesa (downloaded on: 16.08.2010).

The world IBM studies conducted in the years 2007-2008 (Fig. 3) show that more than three quarters of surveyed representatives of managerial staff sees an opportunity in the emergence of new and demanding consumers. Entrepreneurs surveyed in 2010 sustain the claim that changes occurring in consumer expectations are not a threat, but an opportunity for devel- opment (IBM, CEO Study..., 2010). Managerial staff perceives them as factors:

- stimulating changes in the company model;

- opening an opportunity to develop more diversified products or services;

- increasing the ability of companies to gain advantage over competition.

Fig. 3. Influence of new and demanding consumers on the company

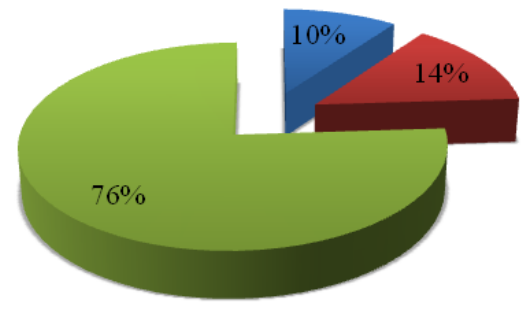

\footnotetext{
Negative influence of new

consumers

匹No influence of new consumers

Negative influence of new

consumers
} 
It is thought that the majority of investment project (Fig. 4) aimed at satisfying the expectations of new and demanding consumers should be directed at new operational possibilities, which will improve coopera- tion and increase the company's innovativeness. Companies which are more effective in operational terms expect that $20 \%$ of their future revenue will come from new sources (IBM, CEO Study..., 2010).

Fig. 4. The level of investment projects targeted at the new consumer category (i.e. better informed and willing to share their knowledge about the quality of products or services)

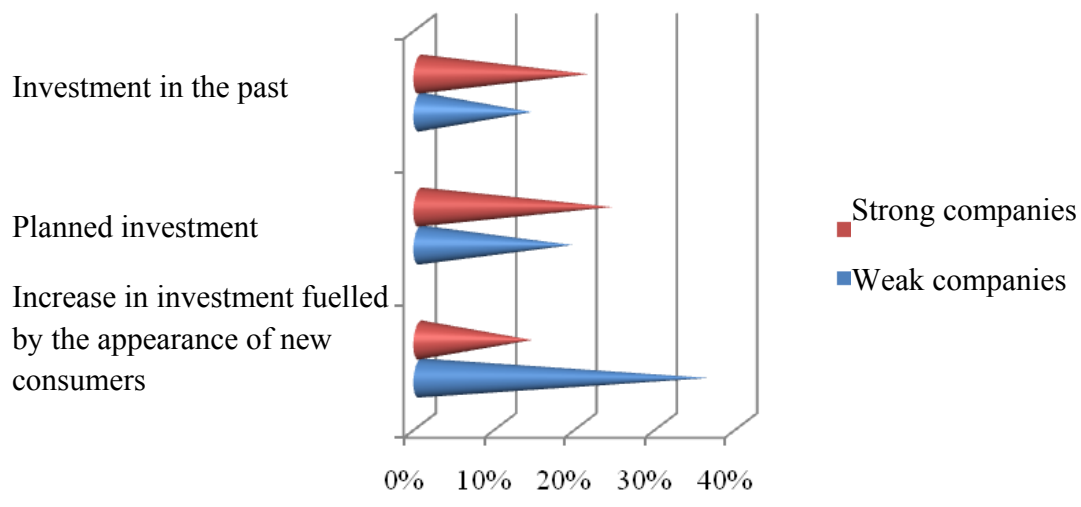

Source: IBM Global CEO Study, 2008: 27.

The reformulation of the strategy of company actions is necessary. It is shown that, as a result of more intense competition and changes in technologies and needs, the average life-span of a company has been reduced. Companies, which are incapable of keeping up with market changes and which do not make an effort to meet consumer expectations, automatically disappear from the market. The period during which a company is listed by, e.g. Standard \& Poor's 500, has been reduced by approx. $80 \%$ - from 75 years in the late 1930s to 15 years in 2000 (Hagel \& Brown, 2006: 23).

\section{Neuroeconomic conditions of the consumer's and entrepreneur's eco- nomic activity}

The understanding of an individual's intentions on the basis of the observation of their behaviour is the basic element of all social relations, such as the consumer-entrepreneur relationship. As research reveals, the recognition of such intentions begins at the level of a system using the mechanism of the so-called mirror neurons ${ }^{14}$.
The existing neural mechanisms enhancing empathy and inclination to cooperation and pro-social behaviour by social exchange lead to the creation and, subsequently, consolidation of relations between people (Adolphs, 2003: 165-170). In people capable of cooperation, greater activity is shown by the areas of prefrontal cortex (Krueger, Barbey, McCabe, Strenziok, Zamboni, Solomon et al., 2009: 22486; Krueger, Grafman \& McCabe, 2008: 3859) connected with control over impulsive behaviour and the ability to postpone gratification (Blakemore \& Frith, 2008: 24; Sanfey, Rilling, Aronson, Nystrom \& Cohen, 2003: 1755-1756).

The signs of lack of bonds between individuals, hostile attitudes and a tendency to commit acts contrary to the applicable system of values in a given society are typical of the behaviour of some people within a given social group. Research by Harrisona \& Fiske (2006: 847-853) showed that there is no neural basis of social cognition in this group of people by means of magnetic resonance imaging. 

ness, as (a sense of) satisfaction, is considered to be tantamount to the achievement of happiness by a human being. This is not true as satisfaction is an emotion based on the result of a right and conscious decision, the effect of a conscious choice; happiness is a subjective sense of a positive influence of events, which took place with the participation of other individuals or without it. The basic difference lies in the appearance of responsibility for decisions taken independently. Therefore, satisfaction as an emotion is connected with brain activity - the activity of individual neurons in the LIP area (lateral intraparietal area) - a region located just above the ears and extending backwards. This area is connected with attention, decision-making and movement planning (Goldberg, Bisley, Powell, Gottlieb \& Kusunoki, 2002: 212,214; Hamed, Duhamel \& Bremmer, 2001).

Changes in the LIP activity are correlated with changes affecting economic decisions made by individuals, i.e. when the reward value increases (usefulness - in the case of the satisfaction of needs), the frequency of the activity of neurons processing appropriate information rises (Platt \& Glimcher, 1999: 234). Therefore, the brain is equipped with networks of neurons involved in the process of calculating values and usefulness, and, consequently, in pure market decisions (Knutson i Peterson, 2005: 305-315). As neuroanatomical studies confirm, people generally exhibit greater sensitivity to loss than to profit (Tom, Fox, Trepel \& Poldrack, 2007: 515-517).

According to research by Russell Poldrack \& Craig Fox, the correlation between the activity of neurons in the LIP area (brain activity) and decisions (behaviour) amounts to 0.85 and the determination coefficient is 0.72 . This means that as much as $72 \%$ of the variance (diversification) of the decisions made by people can be accounted for by means of brain activity (Shermer, 2009: 186-187). The results of research by Fox \& Poldrack attract interest as the determination coefficient is usually below 0.20 .

\section{Conclusions}

In Poland, gradual redefinition of key innovation factors occurs. According to entrepreneurs, getting closer to consumers and satisfying their needs are their most important strategic initiative in the next few years (over $90 \%$ of Polish entrepreneurs). Over $75 \%$ of represen- tatives of the world's managerial staff, also including Polish managerial staff (according to IBM Global Business Services) notices the influence of well-informed consumers (i.e. more demanding, better informed and more willing to share their knowledge about the quality of the product or service) on the development of the company and, therefore, the majority of them expresses the willingness to increase their investment and to improve the operational efficiency to react more promptly to signals coming from the market, better use of experience. Consumers are perceived as participants of market game fulfilling two functions: firstly - creators of innovative activity based on the reported potential demand; secondly - evaluators of the results of innovative actions by the effective demand.

As shown by the results of neuroanatomical research, neuronal modules located in the brain of each individual are responsible for decisions, including market decisions. Each choice is a completely real process engaging a specific number of neurons, as a result of which specific behaviour occurs. As an individual develops, networks of internal neural connections develop and consolidate under the influence of the experience gained. The basic, universal brain architecture is common for all people. However, under the influence of new experiences, neurons beomce stimulated and, in response, they create new synaptic connections, which are the individual property of a particular brain.

The network of brain connections in an individual's brain constantly changes with the intensification of actions undertaken. Contrary to previous assumptions, brain plasticity is not limited only to childhood. During sensitive periods in an individual's development, some brain regions keep developing throughout adolescence and even during adulthood. It means that whenever an individual gains knowledge or experience, the brain structure becomes flexible. As a result, an individual activates new/modified expectations. And they constitute an impulse for another loop of market dependence between the consumer and the enterprise.

\section{References}

1. Adolphs, R., Cognitive Neuroscience of Human Social Behavior, Nature Reviews Neuroscience 4 (March) 2003

2. Allman, J.M., Watson, K.K., Tetreault, N.A., Hakeem, A.Y., Intuition and Autism: A Possible 
Role for Von Economo Neurons, Trends in Cognitive Sciences, 9 (8), 2005.

3. Awazu, Y., Baloh, P., Desouza, K.C., Wecht, Ch.H., Kim, J., Jha, S., Information - Communication Technologies Open Up Innovation, Research Technology Management, 52 (1), 2009.

4. Balsano, T.J., Goodrich, N.E., Lee, R.K., Miley, J.W., Morse, T.F, Roberts, D.A., Identify Your Innovation Enablers and Inhibitors, Research Technology Management, 51 (6), 2008.

5. Blakemore, S-J., Frith, U., Jak uczy się mózg, Wydawnictwo Uniwersytetu Jagiellońskiego, Kraków 2008.

6. Bugdol, M., Wartości organizacyjne. Szkice z teorii organizacji i zarządzania, Wydawnictwo Uniwersytetu Jagiellońskiego, Cracow 2006.

7. Bywalec, Cz., Konsumpcja a rozwój gospodarczy i społeczny, Wydawnictwo C.H.Beck, Warsaw 2010.

8. Cantner, U., Güth, W., Nicklisch, A., Weiland, T., Competition in Product Design: An Experiment Exploring Innovation Behavior, Metroeconomica 60 (4), 2009.

9. Duraj,J.,Papiernik-Wojdera,M.,Przedsiębiorczość i innowacyjność, Difin, Warsaw 2010.

10. European Innovation Scoreboard (EIS) 2009. Comparative analysis of innovation performance, European Union, 2010, http://www.proinno-europe.eu/ page/european-innovation-scoreboard-2009.

11. Gallagher, H.L., Frith, Ch.D., Functional Imaging of "Theory of Mind", Trends in Cognitive Sciences, 7 (2), 2003.

12. Gilbert, R.J., Competition and innovation, Journal of Industrial Organization Education, 1 (article 8), 2006.

13. Goldberg, M.E., Bisley, J., Powell, K.D., Gottlieb, J., Kusunoki, M., The Role of the lateral intraparietal area of the monkey in the generation of saccades and visuospatial attention, Annals New York Academy of Sciences, 956, 2002.

14. Grudzewski, W.A., Hejduk, I.K., Zarządzanie technologiami. Zaawansowane technologie i wyzwania ich komercjalizacji, Difin, Warsaw 2008.

15. Grudzewski, W.A., Hejduk, I.K., Sankowska, A., Wańtuchowicz, M., Sustainability w biznesie, czyli przedsiębiorstwo przyszłości. Zmiany paradygmatów i koncepcji zarządzania, Poltext, Warsaw 2010.
16. GUS, Działalność innowacyjna przedsiębiorstw przemysłowych w latach 1998-2000, Warsaw 2001.

17. Hagel, J., Brown, J.S., Organizacja jutra: zarządzanie talentem, współpraca i specjalizacją, Helion, Gliwice 2006.

18. Hamed, S.B., Duhamel, J.R., Bremmer, F., Graf, W., Representation of the visual field in the lateral intraparietal area of macaque monkeys: a quantitative receptive field analysis, Experimental Brain Research (140), Springer-Verlag 2001.

19. Hardin, R., Zaufanie, Wydawnictwo Sic, Warsaw 2009.

20. Harris, L.T., Fiske, S.T., Dehumanizing the lowest of the low. Neuroimaging responses to extreme out-groups, Psychological Science, 17 (10), 2006.

21. Horn, P.M., The changing nature of innovation, Research - Technology Management, 48 (6), 2005.

22. IBM, Global CEO Study; available at: http://ceo. cxo.pl/news/171343/Wyniki.badania.IBM.Global. CEO.Study.dla.rynku.MSP.html

23. [28.10.2010].

24. Innovation - The New Reality for National Prosperity, National Innovation Initiative, 21st Century Working Group Report, Council on Competitiveness, Washington 2004.

25. Kalinowski, T.B., Innowacyjność przedsiębiorstw a systemy zarządzania jakością, Oficyna a Wolters Kluwer Business, Warsaw 2010.

26. Knutson, B., Peterson, R., Neurally Reconstructing Expected Utility, Games and Economic Behavior, 52, 2005.

27. Krueger, F., Grafman, J., McCabe, K., Neural correlates of economic game playing, Philosophical Transactions of The Royal Society B-Biological Sciences, 363, 2008.

28. Krueger, F., Barbey, A.K., McCabe, K., Strenziok, M., Zamboni, G., Solomon, J., Raymont, V., Grafman, J., The neural bases of key competencies of emotional intelligence, PNAS, 52 (106), 2009.

29. Kucuk, S.U., The evolution of market equalization on the Internet, Journal of Research for Consumers, 16, 2009.

30. Lee, D., Game theory and neural basis of social decision making, Nature Neurosience, 11, 2008.

31. Lee, J.A., Soutar, G.N., Sneddon, J., Personal values and social marketing: Some research suggestions, Journal of Research for Consumers, 18, 2010. 
32. McAdam, R., Moffett, S., Hazlett, S.A., Shevlin, M., Developing a model of innovation implementation for UK SMEs: A path analysis and explanatory case analysis, International Small Business Journal, 28 (3), 2010.

33. McCabe, K., Houser, D., Ryan, L., Smith, V., Trouard, T., A functional imaging study of cooperation in two-person reciprocal exchange, Proceedings of the National Academy of Science, USA 98 (20), 2001.

34. Platt, M.L., Glimcher, P.W, Neural correlates of decision variables in parietal cortex, Nature, 400, 1999.

35. Prahalad, C.K., Krishnan, M.S., Nowa era innowacji, Wydawnictwo Naukowe PWN, Warsaw 2010.

36. Przedpełski, R., Źródła i strategie innowacyjności przedsiębiorstw, Projekt badawczy The Conference Board, Instytut Nauk Ekonomicznych Polskiej Akademii Nauk, Warsaw 2005, http://www. inepan.waw.pl/pliki/siec_naukowa/MSN\%20 WP03.pdf

37. Ramachandran, V.S., Mirror and imitation learning as the driving force behind "The Great Leap Forward" in human evolution, Edge, 69, 2000, http://www.edge.org/3rd_culture/ramachandran/ ramachandran_p1.html

38. Ramachandran, V.S., Mirror Neurons and the Brain in the VAT, Edge, 176, 2006, http://www. edge.org/documents/archive/edge176.html\#rama

39. Ramachandran, V.S., Oberman L.M., Broken mirrors: A theory of autism, Scientific American, May 2006.

40. Rizzolatti, G., Fadiga, L., Gallese, V., Fogassi, L., Premotor cortex and the recognition of motor actions, Cognitive Brain Research, 3, 1996.

41. Rudnicki, L., Zachowania rynkowe nabywców. Mechanizmy i uwarunkowania, Wydawnictwo Akademii Ekonomicznej w Krakowie, Kraków, 2004.

42. Sanfey, A.G., Rilling, J.K., Aronson, A.A., Nystrom, L.E., Cohen, J.D., The neural basis of economic decision-making in the ultimatum game, Science, 300 (5626), 2003.

43. Shermer, M., Rynkowy umysł, Wydawnictwo CiS, Warsaw 2009.

44. Slowinski, G., Hummel, E., Gupta, A., Gilmont, E.R., Effective practices of sourcing innovation, Research - Technology Management, 52 (1), 2009.
45. Tom, S.M., Fox, C., Trepel, Ch., Poldrack, R.A., The neural basis of loss aversion in decision-making under risk, Science, 315 (5811), 2007.

46. Vyas, V., Imitation, Incremental innovation and climb down: A strategy for survival and growth of new ventures, Journal of Entrepreneurship, 14 (2), 2005.

47. Watson, K.K., Jones, T.K., Allman, J.M., Dendritic architecture of the Von Economo neurons, Neuroscience, 141, 2006.

48. Zak, P.J., Values and Value: Moral Economics, [w:] Moral Markets: The Critical Role of Values in the Economy, Zak P. (ed.), Princeton NJ: Princeton University Press, 2008.

49. Żołnierski, A., Potencjał innowacyjny polskich małych i średniej wielkości przedsiębiorstw, Polska Agencja Rozwoju Przedsiębiorczości, Warsaw 2005.

\section{Notes}

1. European Innovation Scoreboard (EIS) has been published every year since 2001. The report is used to present the level and dynamics of innovation changes in EU member states. The EIS methodology was modified in 2008. The number of analysed dimensions of innovation was increased to 7 and it was divided into 3 main blocks: (1) internal activity, (2) company activity, (3) external activity. The blocks constitute a set of connected indices which make it possible to obtain an assessment of an economy's innovation. The blocks and their composition were designed to include the diversity of changes in innovative processes in the intereconomic context. According to the report, the most innovative economies include: Sweden, Finland, Germany, Great Britain, Denmark, which belong to the so-called innovation leaders.

2. The Czech Republic, Portugal, Greece, Hungary, Italy, Lithuania, Malta, Slovakia, Spain belong to the group of moderate innovators.

3. Neuroeconomics is a branch of economics which studies the causes of and forecasts future human behaviour. It is based on three disciplines: economics, neurology and psychology. The establishment of neuroeconomics was the reason and the result of combining tools (both theoretical and empirical ones) used in the three disciplines for a common 

of the misfortune of theirs or when we witness it or when we managed to realise it in a vivid manner.

15. The idea of reorganisation of connections under the influence of experience is referred to as Hebbian (from the name of its advocate - Donald Hebb). The mechanism of Hebbian learning means, in other words, long-term potentation (LTP), whose essence consists in a constant increase in the synapsis efficiency, which results from neural stimulation. Stronger connections between nerve cells and long-term lesions \& synaptic connections are a consequence of LTP. These changes are responsible for learning and memory (Shermer, 2009: 136-137). 